\title{
NEW ANTS FROM THE PHILIPPINES
}

\author{
By William Morton Wheeler \\ Biological Laboratories, Harvard University
}

The following species and subspecies are selected for description on account of their unusual interest from several rich collections of Philippine ants received from Dr. J. W. Chapman, Dr. F. X. Williams, Dr. R. C. McGregor and others.

Metapone gracilis sp. nov.

Female. Length $7 \mathrm{~mm}$.

Head suboblong, about two-fifths longer than broad, slightly broader in front than behind, with feebly concave sides and somewhat sinuate posterior border. Eyes large, rather flat, about one and one-half times as long as their distance from the anterior corners of the head. Anterior ocellus distinctly larger than those of the posterior pair. Mandibles convex, with oblique, coarsely and bluntly 5toothed apical and straight external borders. Median portion of clypeus trapezoidal, flat, sloping, slightly narrowed in front, with straight sides, posterior suture slightly arcuate, not impressed, anterior border only slightly projecting in the middle where it terminates in a pair of broad, blunt teeth. Frontal carinæ subparallel behind, their anterior lobes obtusely angular. Frontal groove distinct. Antennal scapes flattened, nearly four times as long as broad; club of funiculi large, flat, much longer than the remaining joints together, the terminal joint longer than broad, as long as the combined two preceding joints; joints 2-7 much broader than long but gradually increasing in length distally. Thorax slender, nearly four times as long as broad, subhexagonal from above, widest at its middle where the wings are inserted. Pronotum nearly as long as broad, with straight, anteriorly converging, scarcely submarginate sides. Mesonotum somewhat broader than long, flattened above, with arcuate promesonotal suture. Scutellum semicircular, flat. Epinotum longer than broad, in profile sharply 
rectangular behind, the base feebly convex, about four times as long as the abrupt and slightly concave declivity. Petiolar node flattened above, about one and one-third times as long as broad, distinctly broader behind than in front, with sharp anterior and posterior corners, straight, marginate sides and anterior border and arcuately excised posterior border; in profile somewhat longer than high, the anterior surface of the nodes straight and perpendicular, the dorsal surface straight and horizontal, the posterior surface concave, the ventral surface anteriorly with a laterally compressed, triangular, translucent lamella and posteriorly with a thick, transverse projection. Postpetiole subelliptical, broader than long, somewhat broader than the petiole and slightly narrower in front than behind, its dorsal surface feebly convex in profile, perpendicularly truncated anteriorly, its ventral surface with a transverse welt anteriorly. Gaster slender, more than three times as long as broad, first segment decidedly longer than broad, the second broader than long. Legs short, shaped as in the other species, the flattened, middle and hind femora less than twice as long as broad. Wings short, measuring only about $4 \mathrm{~mm}$.

Moderately shining mandibles coarsely striate-punctate; clypeus, head an throax evenly, longitudinally rugulose; pedicel and gaster finely reticulate, with coarse, sparse, piligerous punctures; scapes and legs smoother and more shining, with finer and more scattered punctures.

Pilosity yellowish, short and moderately abundant, oblique on the head and thorax, longer on the legs and abdomen, appressed or subappressed on the latter; anterior border of pronotum with a few conspicuously long, erect hairs. Wings covered with short, brown hairs.

Black; mandibles, clypeus, anterior borders of cheeks and posterior borders of postpetiole and gastric segments reddish brown; tips of scapes, funiculi, trochanters, basitarsi, tips and bases of femora and tibiæ more yellowish brown; remaining tarsal joints yellow. Wing membranes brownish; veins and peterostigma dark brown.

Described from a single specimen captured by Prof. C. F. Baker at Dapitan, on Mindanao Island, Philippines. 
$M$. gracilis belong to the group of species comprising bakeri Wheeler of the Philippines, tillyardi Wheeler of New South Wales, johni Karawajew of Ceylon and jacobsoni Crawley of Sumatra and characterized by having the clypeus narrowed and blunt or bidentate anteriorly instead of terminating in a rectagular lobe with acute corners. Crawley mentions two female specimens under his description of jacobsoni, taken in April and October, 1914, respectively. The former he regards as the type of jacobsoni, the latter, which is very similar to the female described above, is, I believe, specifically different. There must be several closely related, still undescribed species of Metapone in the Indomalayan and Indonesian regions. I possess males of two species from Singapore and Luzon Island, which differ from the one I described as hewitti from Borneo, but I refrain from describing them till the cospecific females or workers turn up.

Prosopidris subgen. nov. (of Cardiocondyla)

Worker. Minute and closely related to Cardiocondyla. Antennæ very similar, but 11- instead of 12-jointed. Clypeus much larger, thick and swollen, perpendicularly truncated anteriorly and forming on each side a strong, oblique welt which bounds the antennal fossa. Thorax stout and rather high, evenly arcuate above in profile, without promesonotal and mesoëpinotal sutures and mesoëpinotal impression; epinotum armed with a pair of stout spines. Petiole much as in Cardiocondyla but the node more concave anteriorly; postpetiole large, broader than the petiolar node, as in that genus. Gaster consisting very largely of the first segment. Sting well-developed, short and stout. Middle and hind tibiæ without traces of spurs; tarsal claws very small, simple. Pilosity lacking except on the mandibles and clypeus; sculpture feeble as in Cardiocondyla.

Female. Not much larger than the worker and very similar to the female of Cardiocondyla in the structure of the thorax. Postpetiole not more enlarged in proportion to the petiolar node than in the worker. Wing-venation much as in Cardiocondyla with narrow pterostigma near the middle of the costal border, a single narrow cubital cell, no 
discoidal cell, and only a short basal piece of the radial vein, but with a well developed discoidal vein.

Subgenotype: Cardiocondyla (Prosopidris) sima sp. nov.

Cardiocondyla (Prosopidris) sima sp. nov. (Fig. 1)

Worker. Length 2-2.2 $\mathrm{mm}$.

Head subrectangular, longer than broad, nearly as broad in front as behind, with straight, subparallel sides, broadly rounded posterior corners and feebly sinuate posterior border. Eyes moderately large and convex, somewhat longer

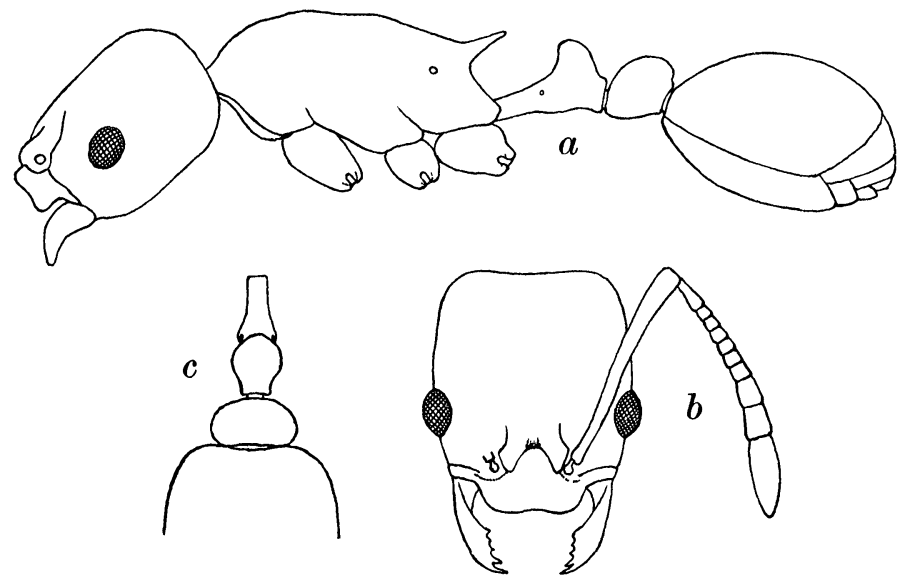

FIg. 1. Cardiocondyla (Prosopidris) sima sp. nov. Worker; $a$, in profile; $b$, head, dorsal view ; $c$, petiole and postpetiole, dorsal view.

than their distance from the clypeus. Mandibles convex, 5 -toothed, the two apical decidedly larger than the basal teeth. Clypeus projecting over the bases of the mandibles, its anterior truncated surface flattened, its posterior portion extending back between the frontal carinæ large, convex, subtriangular, its anterior border transverse, feebly sinuate in the middle and more deeply sinuate on each side. Frontal area small, triangular, impressed and rather indistinct; frontal groove distinct anteriorly. Antennæ slender, scapes nearly straight, extending somewhat beyond the posterior corners of the head; second funicular joint longer than broad, joints 3-7 as long as broad, the two basal joints 
of the club longer than broad, subequal, together shorter than the distinctly swollen terminal joint. Pronotum with the neck as long as broad, with broadly rounded humeri; mesonotum broader than long, narrowed posteriorly where the pleuræ are distinctly compressed; epinotum longer than broad, slightly narrowed anteriorly, its posteriorly sloping base one and two-thirds times as long as the perpendicular declivity, which is concave in the middle and marginate on the sides, metasternal angles prominent but rounded, the spines straight, blunt and stout, nearly as long as the distance between their bases but shorter than the declivity, directed backward and outward and slightly upward. Peduncle of petiole as long as the node, which is as high as long, rounded above and distinctly broader than long. Post-petiole transversely elliptical, lower and nearly twice as broad as the petiolar node, convex anteriorly, with its straight posterior border. Gaster broadly elliptical, convex, with broadly concave anterior border. Legs rather long.

Thorax, pedicel and gaster distinctly shining, microscopically and superficially reticulate or punctulate; mandibles, clypeus, head and appendages more opaque, the head and anterior portion of pronotum more sharply and coarsely punctulate and also covered dorsally with shallow and not very distinct foveolæ.

Pilosity and pubescence yellowish, the former consisting of a few short, sparse, erect hairs on the clypeus and mandibles, the latter fine, dilute, appressed, longer and more distinct on the gaster and appendages.

Dull yellowish brown or pale ferruginous, the head very slightly darker, the mandibles, clypeus, peduncle of petiole and appendages slightly paler. Mandibular teeth dark brown.

Female. Length 2.7-2.8 mm.

Very similar to the worker; joints 3-7 of funiculi distinctly broader than long; thorax short, as broad as the head; pronotum somewhat flattened, broader than long, subtriangular anteriorly; epinotal spines shorter and stouter than in the worker, subparallel; petiole and postpetiole not enlarged as compared with the worker. 
Sculpture and pilosity as in the worker except that the whole thorax above is foveolate-punctate like the head, and the thorax, nodes of pedicel and gaster are darker and less yellowish, being as dark as the head. Wings grayish; veins brown, pterostigma dark brown.

Described from eight workers and four females collected by Mr. L. M. Morato at Dansalan, on Lanao Island, Philippines, and received from Dr. J. W. Chapman.

Dilobocondyla chapmani Wheeler subsp. rufobrunnea subsp. nov.

Worker. Length $3.8 \mathrm{~mm}$.

Differing from the typical chapmani in its slightly larger size, slightly more opaque surface throughout and in coloration, being dark brown, with the pronotum above paler and more rufous, the mandibles, except the teeth, the sides of the clypeus, scapes, first funicular joint and tarsi beyond their first joint, brownish yellow.

Female. Length $4.5 \mathrm{~mm}$.

Very similar to the worker, but the gular surface of the head and the thorax are paler and more reddish than the head and gaster, the postscutellum and posterior portion of the mesonotum infuscated. Wings shorter than the body, whitish, with pale brown veins and dark brown peterostigma. The radial cell is short and closed, there is a single cubital but no discoidal cell.

Male. Length $4.3 \mathrm{~mm}$.

Head broader than long, transversely elliptical, with large eyes and moderately large ocelli. Cheeks short and strongly converging anteriorly. Mandibles well-developed, flattened, 5 -toothed, the two basal teeth small. Clypeus broad, feebly convex, its anterior border broadly rounded, entire, sinuate on each side. Frontal area large; frontal carinate short, low and subparallel. Antennæ long, 13-jointed; scapes very short, only about twice as long as broad; first funicular slightly longer than broad, not swollen, remaining joints cylindrical, the second twice as long as the scapes, the remaining joints shorter, except the last, which is nearly as long as the second and somewhat swollen. Thorax through the mesonotum somewhat broader than the head; pronotum 
very short, mesonotum large and convex, with very pronounced notauli (Mayrian furrows) ; epinotum higher than long, with subequal base and declivity, the former distinctly convex, the latter flattened, perpendicular and marginate on each side. Petiole and post-petiole similar to those of the worker, but more slender. Gaster small, elongate-elliptical; genitalia exserted, the stipites rather large, lobular, rounded at the tip. Legs long and slender but the femora distinctly incrassated in the middle, though less so than in the worker.

Somewhat shining; mandibles finely reticulate; head longitudinally rugulose, the clypeus and frontal area more finely and more regularly than the cheeks, the rugules of which curve around the antennal fossæ. The interrugal spaces are sharply and finely reticulate as in the worker. Sculpture of thorax similar; pronotum transversely, mesonotum longitudinally rugulose; scutellum more coarsely reticulate-rugulose, pleuræ and epinotal declivity smoother. Petiole, postpetiole and gaster shining, smoother, only superficially and microscopically reticulate.

Pilosity longer than in the worker, the hairs tapering and flexuous.

Black; scapes, gaster, coxæ and femora dark brown; base of gaster above somewhat infuscated; tibiæ, tarsi and funiculi white; first funicular joint strongly, tibiæ feebly tinged with reddish brown; wings whitish, veins colorless, pterostigma pale brown.

Single worker, female and male specimens collected by Mr. W. D. Pierce at Victoria, Negros Oriental, Philippines, and received from Dr. J. W. Chapman.

Emery, in the "Genera Insectorum" (p. 241) described with a query a male specimen of an undetermined species of Dilobocondyla from Sumatra. The foregoing description of the rnale collected with the cospecific worker shows that he really had a male Dilobocondyla, probably belonging either to D. sebesiana Wheeler or to D. karnyi Wheeler.

Zatapinoma williamsi sp. nov.

Soldier. Length nearly $3 \mathrm{~mm}$.

Very similar to the soldier of $Z$. annandalei Wheeler of 
India but differing in the following characters: Integument thicker and more rigid, clypeal swellings somewhat less pronounced and not bilobed or biprotuberant on each side; mandibles with 8 coarse teeth, the first, second and fourth larger than the others, the seventh and eighth fused; frontal area obsolete; funicular joints 3-8 as long as broad (in annandalei distinctly broader than long); eyes distinctly larger, situated a distance equal to their greatest diameter from the posterior clypeal border, which is more distinct than in the Indian species. Thorax more slender, the pronotum as long as broad, the epinotum slightly longer than broad.

Sculpture and pilosity very similar in the two species, but the color of williamsi is different, being brownish yellow instead of whitish yellow, the mandibles and clypeus are concolorous with the remainder of the head and the second to fourth gastric segments are brown at the base.

Female. Length $3.5 \mathrm{~mm}$.

Resembling the soldier, but the head is proportionally smaller and somewhat more narrowed anteriorly, the eyes though flat are much larger, twice as long as their distance from the anterior corners of the head. Ocelli well-developed, near the occipital border. Clypeus without the peculiar lateral swellings of the soldier, feebly convex in the middle, depressed on each side. Frontal area large and indistinct. Antennal scapes reaching to the posterior fourth of the head. Thorax collapsed, but apparently as broad as the head, with flattened mesonotum. Gaster large, shaped like that of the soldier. Wings long, the anterior pair with long closed radial cell, a single long cubital but no discoidal cell. There are no traces of a pterostigma.

Sculpture and pilosity much as in the soldier, but the pubescence is more abundant and longer, especially on the gaster and the segments of this region also bear sparse and rather long, coarse hairs. Wings pubescent.

Clypeus and thorax brown; antennæ, head and legs brownish yellow; gaster pale yellow, with a broad, dark brown basal fascia on each segment. Wings hyaline, with very pale yellow veins. 
Single soldier and female specimens taken by Dr. F. X. Williams as Los Banos, Luzon Island, Philippines.

This species is very close to $Z$. wheeleri described and figured by Dr. W. M. Mann in the present issue of "Psyche" from soldiers received from Samoa by the Federal Quarantine Station in Honolulu. This species, however, has 5toothed mandibles and the funicular joints 2-10 are distinctly broader than long as in $Z$. annandalei. As I am not certain that the two specimens collected by Dr. Williams are from the same colony, only the soldier is to be regarded as the type.

\section{Acantholepis aurea Karawajew subsp. punctaticeps} subsp. nov.

Worker. Length $2 \mathrm{~mm}$.

Head subtrapezoidal, slightly longer than broad, distinctly narrowed anteriorly, with feebly convex sides and posterior border and rounded posterior corners. Eyes at the middle of the sides of the head, moderately convex, as long as their distance from its anterior corne:s. Mandibles convex, with 5 subequal teeth. Clypeus convex, carinate, with broadly rounded, projecting anterior border. Frontal area obsolescent; frontal groove distinct anteriorly. Antennal scapes extending about one-fourth their length beyond the posterior border of the head. Pronotum with rounded humeri and convex sides and dorsal surface, decidedly broader than long; mesonotum transversely subelliptical, one and one-third times as broad as long; metanotum about two-thirds as broad as the pronotum, with prominent, dorsally projecting spiracles; the mesometanotal impression short but pronounced; epinotum somewhat narrower than the pronotum, subrectangular, the base on each side with a pair of stout longitudinal projections which terminate posteriorly in very blunt teeth bearing the epinotal spiracles at their tips. Petiolar scale thin, its summit acute and almost semicircularly excised, so that its corners from two blunt, flattened teeth which are about twice as long as broad at their bases, its sides and anterior surface somewhat convex. There is no peduncle-like prolongation behind the node. 
Mandibles and clypeus shining, feebly and microscopically reticulate, the former with a few coarse piligerous punctures, remainder of head opaque, densely and finely punctate; thorax, petiole and appendages subopaque, sculptured like the head but more superficially; meso- and metapluræ longitudinally rugulose; gaster smooth and shining.

Hairs white, sparse, erect and obtuse, present only on the body; scapes and legs with fine, appressed, pale pubescence.

Head and thorax dark reddish brown; gula, occiput and epinotum darker and more blackish; mandibles, scapes, mesonotum, trochanters, tips of femora and tips and bases of tibiæ yellowish brown; funiculi fuscous; tarsi yellow, with the last joint brown; gaster black.

Two specimens taken by Dr. J. W. Chapman, one at Baguio, Luzon Island (type locality) and one Dumaguete, Negros Oriental, Phillippines. The second specimen seems to be somewhat immature. I have attached this form to aurea, recently (1932) described by Karawajew from Bantam, at the western end of Java, because it seems to differ only in the decidedly thinner petiolar scale, different sculpture of the head and much darker coloration. Aurea was the first species of Acantholepis to be described from Indonesia, all the other known species of this rather large genus being confined to the Eurasian and African continents, except the Indian A. rothneyi wabsoni Forel which occurs in Formosa. There is among my Philippine material, however, yet another species which is here described.

Acantholepis chapmani sp. nov. (Fig. 2)

Worker. Length 2.5-2.8 $\mathrm{mm}$.

Head suborbicular, convex and rounded behind, including the mandibles slightly longer than broad. Eyes large, convex, somewhat behind the middle of the sides; ocelli large and widely separated. Mandibles moderately convex, 5toothed, the first and fourth tooth from the apex larger than the others. Maxillary palpi very long. Clypeus large, evenly convex, ecarinate, with rounded, entire and projecting anterior border. Frontal area transversely triangular; frontal groove distinct. Antennæ slender; scapes extend- 
ing two-fifths their length beyond the posterior border of the head; all the funicular joints fully twice as long as broad. Thorax shaped as in A. frauenfeldi Mayr but the anterior portion of the mesometanotal constriction is broader, though decidedly longer and more slender than in aurea punctaticeps. Pronotum one and one-third times as long as broad, flattened or slightly concave above, with distinctly protuberant humeri. Mesometanotum twice as long as broad, narrowed in the middle and bearing at its poster-

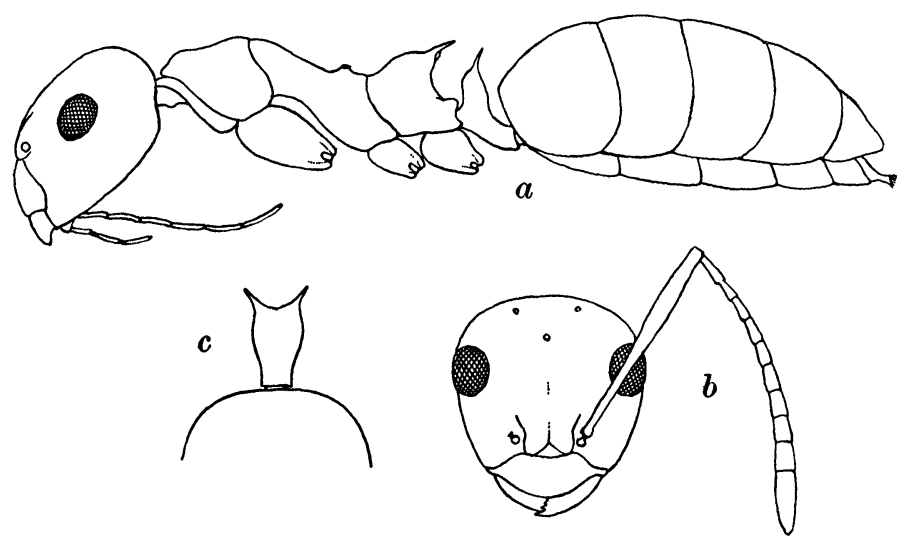

Fig. 2. Acantholepis chapmani sp. nov. Worker; $\alpha$, in profile; $b$, head, dorsal view; $c$, petiole, posterior view.

ior fourth the dorsally projecting spiracles which are separated by a space four times their diameter. Epinotum from above subrectangular, nearly as broad as the pronotum and one-third broader than long, bearing on its anterior or basal half two large, thick, rapidly tapering, rather acute spines. Petiole long, with long posterior peduncle, the anteriorly placed scale inclined forward, convex anteriorly and posteriorly and moderately thick, bearing above at each corner of feebly concave, transverse summit a small, slender, acute spine which is directed upward, outward and slightly backward. Gaster rather large, subelliptical. Legs long and slender.

Shining and very finely and superficially reticulate or shagreened; meso- and epinotum more opaque and more 
coarsely reticulate or densely punctulate and also sharply longitudinally rugulose, the rugules faint or absent anteriorly on the dorsal surface of the mesonotum; neck and posterior peduncle of petiole finely rugulose. Scapes and legs very delicately and densely punctulate.

Hairs and pubescence white, the former sparse, erect and rather short, most numerous on the head and gaster, absent on the appendages which are instead invested with fine, appressed or subappressed pubescence.

Yellow; meso- and epinotum, neck and posterior peduncle of petiole brownish; funiculi beyond the first joint, apical halves of hind femora, except their tips, and the tibiæ except their bases and tips, fuscous; mandibles, palpi and tarsi white; mandibular teeth reddish.

Female (deälated). Length $4.5 \mathrm{~mm}$.

Resembling the female of $A$. frauenfeldi, but the head is proportionately smaller and broader, broader than long, subtrapezoidal. Antennæ shorter and stouter than in the worker. Thorax and petiole as in frauenfeldi, the former elliptical and depressed dorsally, with rounded, spineless epinotum, the latter with a decidedly thicker, spineless scale.

Opaque and much more sharply and densely punctulate throughout than the worker, except the thoracic sutures and an anteromedian impressed line on the mesonotum which are shining.

Pilosity much as in the worker but more abundant on the thoracic dorsum; pubescence distinct on the head, pronotum, gaster and legs; dense but rather short on the gaster.

Dull yellowish red; head somewhat paler; tarsi antennal scapes and first funicular joint yellow; remainder of funiculi brown; three broad, anteriorly fused vittæ on the mesonotum, the mesopleuræ, summit of petiolar scale, dorsum of gaster except the anterior portion of the first segment, dark brown or blackish.

Described from numerous workers and a single female taken by Dr. J. W. Chapman from two colonies nesting in galls on dead branches in the mountains near Dumaguete, Negros Oriental, Philippines. 
Nesolasius subgen. nov. (of Pseudolasius)

Worker maxima. Resembling Pseudolasius but differing in the peculiar conformation of its mandibles, clypeus, frontal carinæ and eyes. Head large, subcordate, rather flat, deeply excised posteriorly. Eyes very small and indistinct, consisting of only a few ommatidia, in front of the middle of the head and on its dorsal surface as in Pseudolasius. Mandibles short, stout and convex, with only four very coarse, subequal teeth on the apical border, which is not oblique; the basal tooth apparently consisting of a fused pair of teeth. Clypeus very short, with a subrectangular median portion not extending back between the frontal carinæ, anteriorly abbreviated, with broadly concave anterior border, and short, band-like lateral portions extending to the sides of the head. Clypeal fossæ deep and pit-like. Frontal carinæ in the form of narrow lobes more closely approximated than in Pseudolasius, sens. str. conspicuously elevated, projecting above the surface of the head and bearing the antennæ beneath their anterior tips, bounded laterally by short scrobe-like impressions which are very narrowly confluent with the clypeal fossæ. Frontal area convex, lying between the frontal carinæ, continued posteriorly as a distinct median ridge instead of a groove and extending as far back as the middle of the head. Antennæ small, 12-jointed; scapes short. Thorax short and stout, shaped much as in Pseudolasius, with large, convex pronotum; metanotum distinct, with dorsolateral spiracles. Epinotal spiracles elliptical. Petiole, gaster and legs as in Pseudolasius.

Genotype: Pseudolasius (Nesolasius) typhlops sp. nov.

Pseudolasius (Nesolasius) typhlops sp. nov. (Fig. 3)

Worker maxima. Length $3.3 \mathrm{~mm}$.

Head about one-fourth longer than broad, as broad in front as behind, with feebly and evenly convex sides and angularly excised posterior border. Eyes consisting of only 3 or 4 scarcely pigmented ommatidia. Clypeus convex in the middle, depressed on the sides. Antennal scapes reaching to the middle of the sides of the head; funicular joints 2-10 as long as broad, first joint as long as the three 
succeeding joints together, terminal joint as long as the two preceding. Thorax including the neck about twice as long as broad, pronotum as broad as long; mesonotum convex, rounded subtriangular, broader than long; epinotum nearly as broad as the mesonotum, its base broader than long, rounding into the longer, feebly concave and nearly perpendicular declivity. Petiolar scale high, moderately thin, inclined forward, narrowed above, with rounded, entire, compressed superior border. Gaster elongate-elliptical. Legs rather stout.

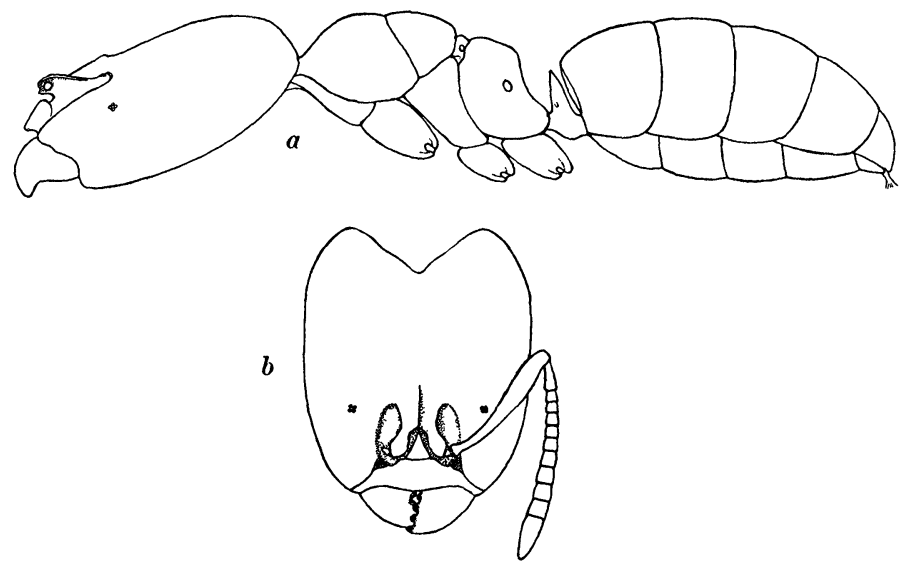

FIG. 3. Pseudolasius (Nesolasius) typhlops sp. nov. Soldier; $a$, in profile; $b$, head, dorsal view.

Mandibles, clypeus, thoracic dorsum and gaster shining, remainder of body subopaque, very finely shagreened, with fine piligerous punctures. Cheeks and antennal fossæ finely, longitudinally striate.

Hairs and pubescence pale yellow, the former long, erect and conspicuous on the gaster, shorter and much sparser on the head and thorax, long on the clypeus; hind tibiæ with a few long and oblique hairs on their extensor surfaces. Pubescence dense, especially on the head, thorax, scapes and legs, much more dilute on the gaster; appressed except on the thoracic dorsum.

Uniformly pale yellow, except the mandibles which are darker and more reddish, with black teeth. 
A single specimen from Los Banos, Luzon Island, Philippines, taken by Dr. F. X. Williams in decaying wood.

The specimen is evidently a worker maxima. The anterior portion of its head is so unusual that it can hardly be assigned to Pseudolasius sens. str., but whether Nesolasius will be regarded by other myrmecologists as an independent genus or as a subgenus of Pseudolasius may depend on the characters of the still unknown castes. Perhaps Forel's Ps. amblyops from the New Britain and his sundaicus from Sumatra should be assigned to Nesolasius. In the former the mandibles are 5-toothed and the eyes are reduced to a single facet. In Ps. amaurops Emery of New Guinea, which measures only 1.6-2 mm., the eyes are similarly reduced but the clypeus, frontal carinæ and 6-toothed mandibles show that it belongs to Pseudolasius sens. str. 

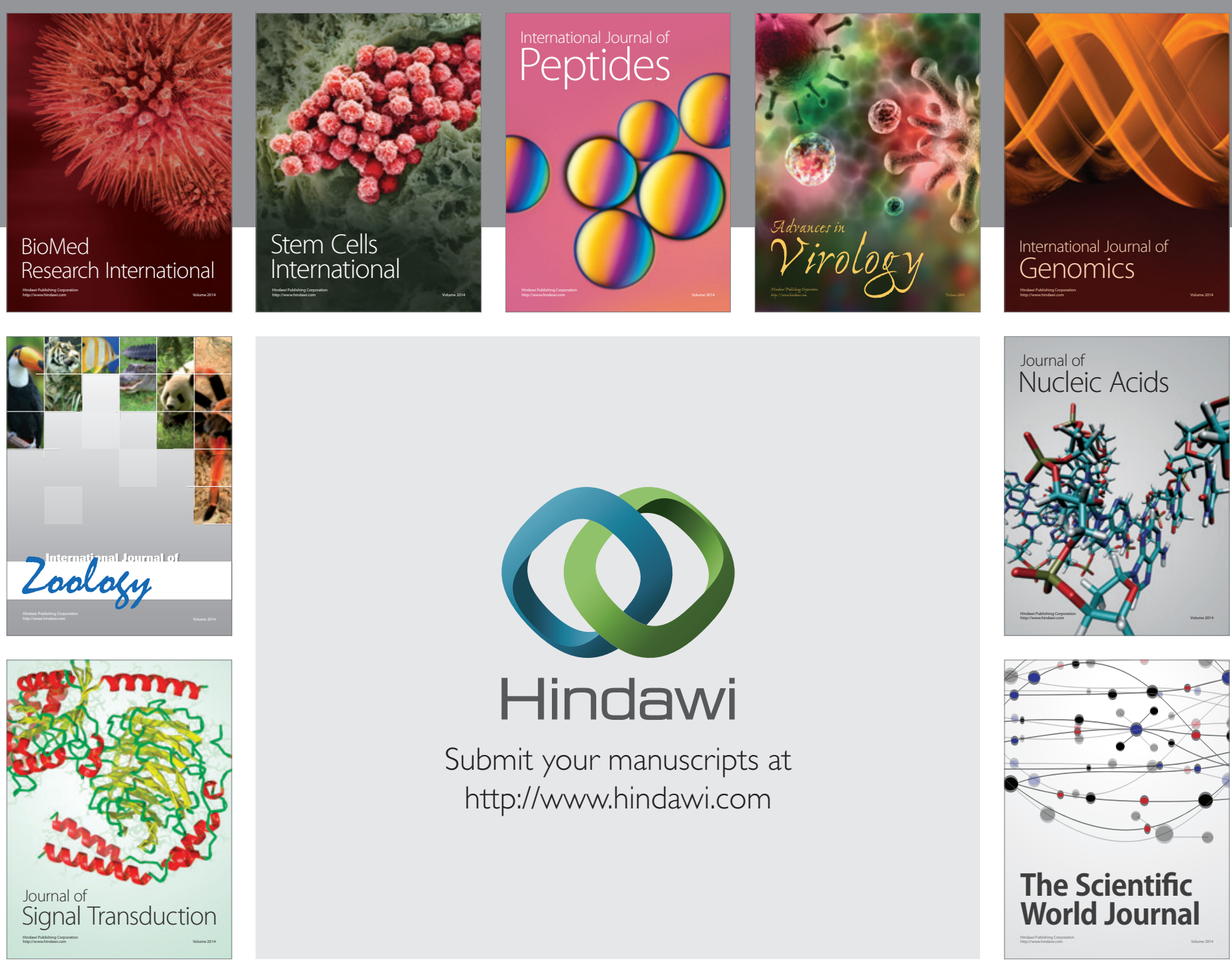

Submit your manuscripts at

http://www.hindawi.com
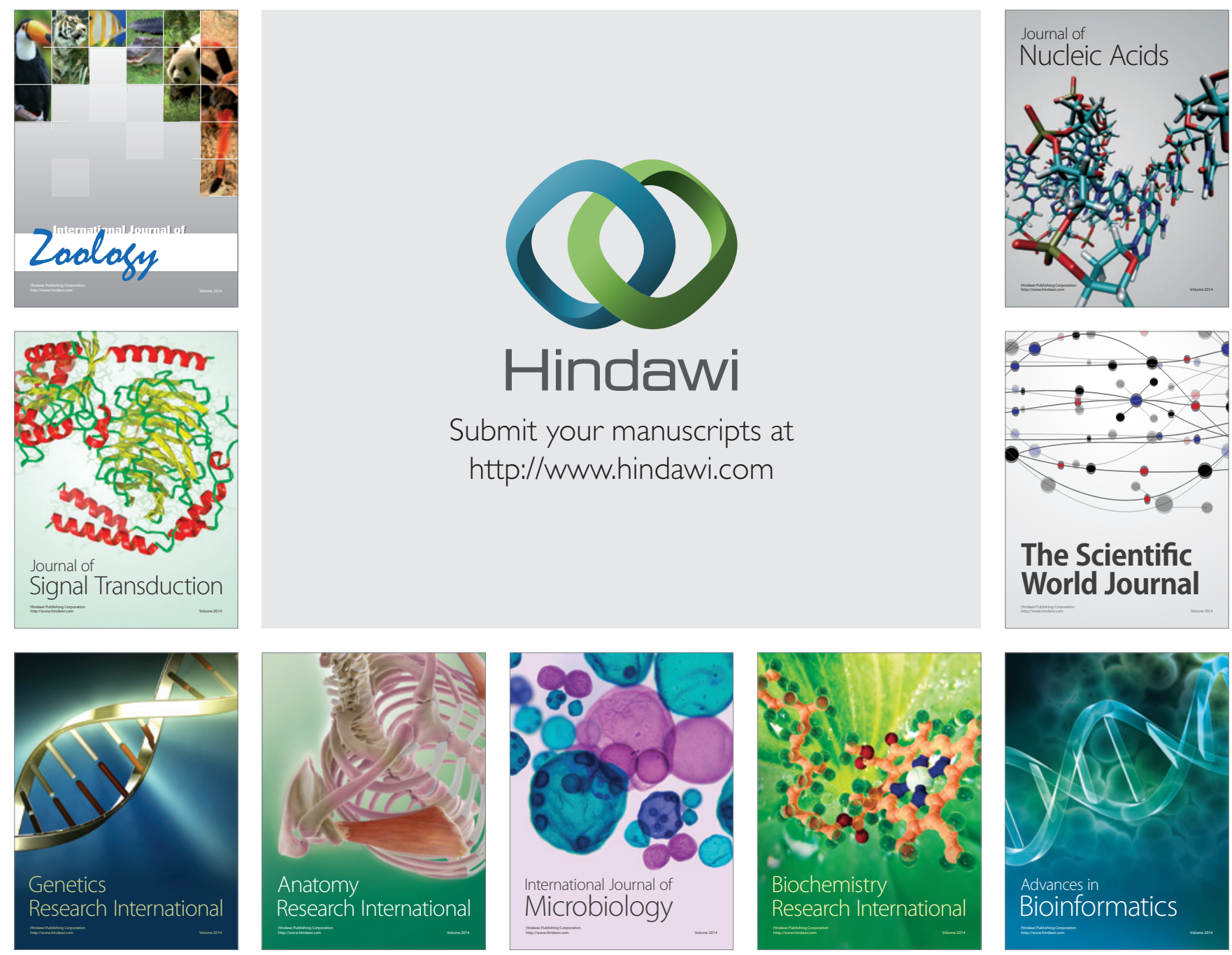

The Scientific World Journal
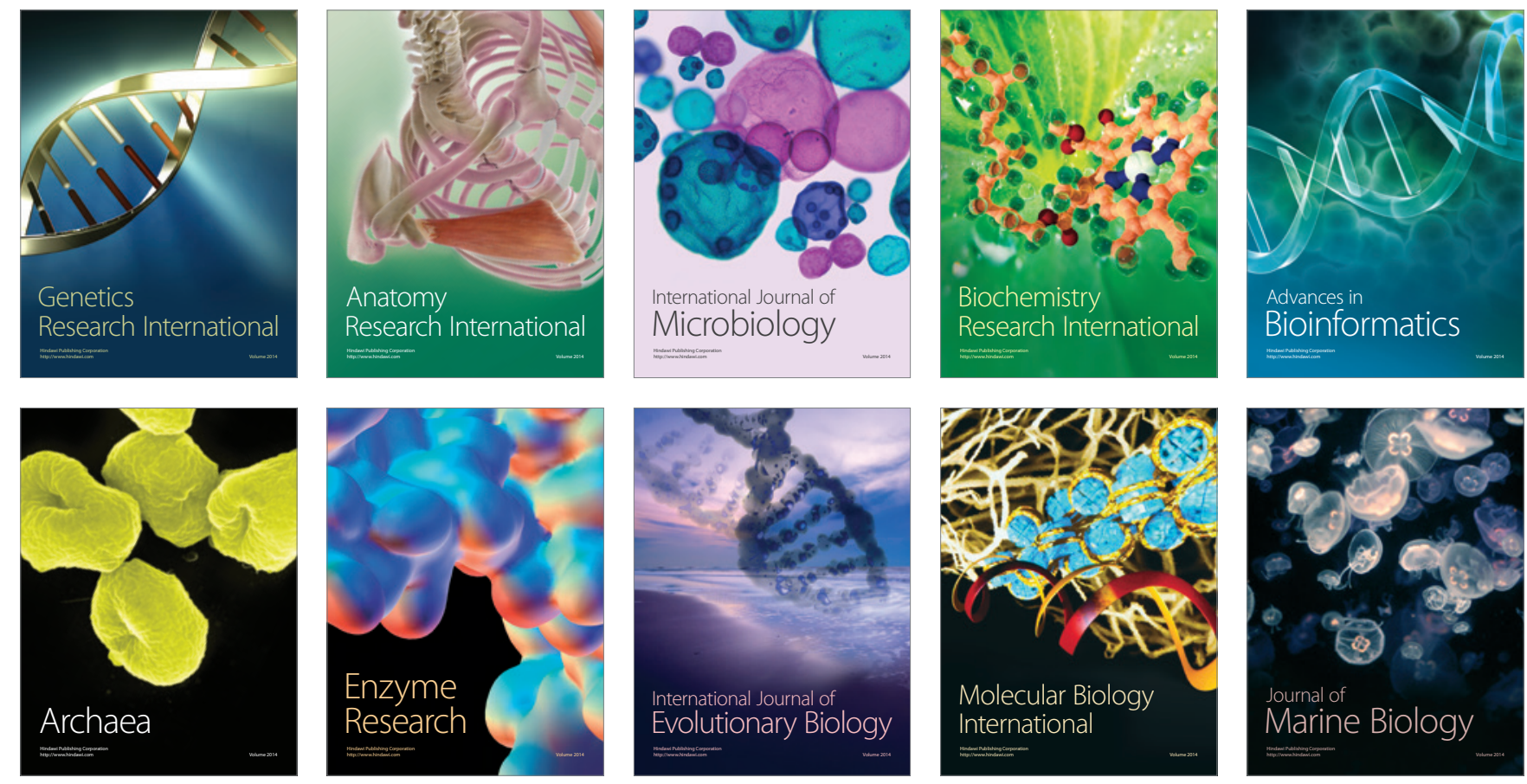